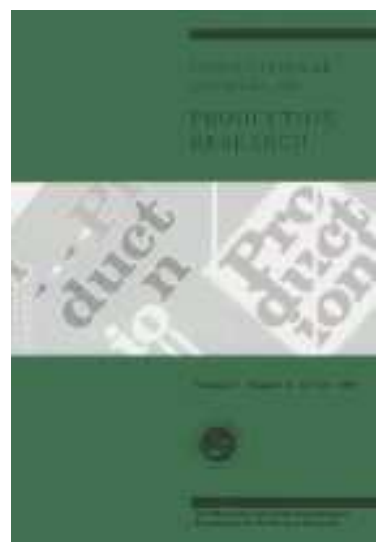

\title{
Aligning Business Process Reengineering in Implementing Global Supply Chain Systems by the SCOR Model
}

\begin{tabular}{|r|l|}
\hline Journal: & International Journal of Production Research \\
\hline Manuscript ID: & TPRS-2009-IJPR-0136.R1 \\
\hline Manuscript Type: & Original Manuscript \\
\hline Author: & 14-May-2009 \\
\hline Complete List of Authors: & $\begin{array}{l}\text { Wang, William; Victoria University of Wellington, School of } \\
\text { Information Management } \\
\text { Chan, Hing; University of East Anglia, Norwich Business School } \\
\text { Pauleen, Paul; Massey University, 3Department of Management and } \\
\text { International Business }\end{array}$ \\
\hline Keywords: & $\begin{array}{l}\text { BUSINESS PROCESS RE-ENGINEERING, SUPPLY CHAIN } \\
\text { MANAGEMENT }\end{array}$ \\
\hline Keywords (user): & SCOR, Metrics \\
\hline
\end{tabular}

\section{S) ScholaroNE \\ Manuscript Central}




\title{
Aligning Business Process Reengineering in Implementing Global Supply Chain Systems by the SCOR Model
}

\author{
William Y C Wang ${ }^{1}$, H. K. Chan ${ }^{2}$, and David J Pauleen ${ }^{3}$ \\ ${ }^{1}$ School of Information Management, Victoria University of Wellington, New Zealand \\ Yuchung.wang@viw.ac.nz \\ ${ }^{2}$ Norwich Business School, University of East Anglia, Norwich, UK. \\ h.chan@uea.ac.uk \\ ${ }^{3}$ Department of Management and International Business, Massey University, New Zealand \\ D.Pauleen@massey.ac.nz
}

\begin{abstract}
As supply chains continue to replace individual companies as the management arena for value-adding from the beginning of the twenty first century, understanding the supply chain management practices in a globalization context becomes increasingly important. The Supply Chain Operations Reference (SCOR) Model, which was developed by the experts and practitioners of the Supply Chain Council, is a major framework for supply chain planning which features supply chain management practices and business process reengineering. Despite being an integrative guide with many merits, it only provides a 'top-down' approach which requires the comparative analyses of post- and pro- performance indices as a basis of business process modification. This study discusses the limitations of current SCOR analysis and provides a mapping technique-Causes/Effects, the SCOR Standard, and Mutual Solution (CESM) - for gap mapping, problem prioritization, and business process modification in a supply chain setting. As such it is one of the early empirical studies combining BPR and SCM disciplines. The research results can facilitate the implementation processes of multinational supply chain projects by identifying the gaps and linking them to the channel entities.
\end{abstract}

Keywords: Business Process Reengineering, SCOR, Metrics, Global Supply Chain Systems,

\section{Introduction}

As supply chain management has become a major contemporary business model, the competition has been transformed from the traditional market-based buyer supplier relations to one of competition among cooperative sets (Patnayakuni, et al. 2006). To manage the supply chain that consists of subordinates, customers, and suppliers, an enterprise needs the large-scale information systems which integrate existing Enterprise Resource Planning (ERP) systems at different sites (Chan and Chan, 2009). Business process reengineering (BPR) has long been suggested in the literature as the key to the implementation of large-scale information systems in the enterprise context (Davenport and Short, 1990; Chen and Tsai, 2008). It is a requirement for systems adoption projects for pre-analysis of organizational services, production activities and business flows. BPR, which focuses on the whole process of business activities, seeks to obtain dramatic and sustainable performance improvement by radically redesigning the organization for process automation. In particular, it aims to reduce 
the number of redundant tasks for improving customer satisfaction, return on investment, and market share (Hales and Savoie, 1994; Hewitt, 1995). However, little evidence exists supporting this kind of reasoning as analytical tasks are mostly carried out by individual informal decisions that may not be carefully linked to relevant business objectives (Gunasekaran and Kobu, 2002). Many failed cases involve systems deployment primarily designed for solving functional and technical problems, without considering the implications for organizational changes engendered during the adoption procedures (Grant, 2003). Successful cases are associated with detailed corporate analyses of the internal operations to establish relationships with their external organizations in order to identify supply/demand fluctuations and amplitudes (Kumar, et al, 2008).

Vernadat (1996) has formalized behaviour rules derived from algebra for structured processes and temporal logic for semi-structured processes in the business context. He suggests two major groups of elements as functional entities (human or non-human agents) and functional operations (performance elementary actions) are driving business processes. This concept subsequently influenced the launch of practical models for BPR implementation such as the process aspect of Balanced Scorecard (Kaplan and Norton, 1996) and the Supply Chain Operations Reference Model (SCOR) (SCC, 2005). While the Balanced Scorecard is well-known for its application to enterprise level improvement, SCOR is utilized as the standard diagnostic tool for the configuration of supply chain management.

The achievement of effective supply chain operation depends on the seamless collaboration of distributors, manufacturers, and suppliers through the application of interorganizational systems (IOS) and evolving technological approaches (Pramatari, 2007). Collaboration in the global supply chain via recent technologies-such as Dell in the information technology industry, Walmart in the retail industry, and General Motors in the automotive industry-can be typically seen as such efforts. While senior managers recognise that managing the supply chain cannot be left to chance, business owners are seeking ways to deal with the complexity of the task. Similar to BPR at enterprise level for ERP adoption, implementing a project of supply chain management and related IOS requires preliminary process-driven analyses and improvements of organization structure, business processes, and the setting up of performance measurements in a supply chain context.

Besides the BPR literature, there are also extensive studies on project management and the implementation of organizational change, many of them advising managers on techniques and practices to use in the flow of goods and services through the supply chain. Other aspects include the form of coordination and partnerships in the channel context (e.g., Macbeth and Ferguson, 1994; Boddy et al., 1998). However, there is insufficient knowledge on changing and adjusting the business processes with supply chain management. Based on a case of implementing global supply chain systems in the fabric industry, this paper attempts to provide a methodology to identify the opportunities of business process modification. SCOR is used and it is also adopted as the reference for business process alignment. In addition, this research presents a detailed framework of global supply chain systems to portray the combination of systems infrastructure, organization units, and business processes to establish a standard for the systems implementation of business sectors and directions for future research.

\section{The SCOR Model and the "Top-Down" Approach}

Integrating operations across all facets of business flows within and beyond the boundaries of companies is one of the keys to success in business today. To reduce costs, practitioners and 
Based on the literature, there are three types of BPR approaches namely, radical change (incremental improvement), the clean slate approach (ignore current situation), and top-down participation (Den Hengst and De Vreede, 2004). Among the three types, SCOR model follows a set of 'top-down' procedures, commencing from the corporate level strategy and then extending to the middle level of business processes and stakeholders. These procedures can help to identify thousands of business activities both inside an organization and across the boundaries of the supply chain entities. The SCOR model includes the following elements as a communication platform for the practitioners of the supply chain planning activities:

- Standard descriptions of each business process along the supply chain are categorised as 'Plan', 'Source', 'Make', 'Delivery' and 'Return' (i.e., return of goods or reverse logistics) and the supportive activities are defined as 'Enabler' (Table 1).

- Key performance indicators (KPI) are classified by the attributes accompanying each of the business processes; e.g., 'Total Source Cycle Time to Completion' is a KPI in the attribute of 'Supply Chain Responsiveness' of Source activities.

- Best practices appear in the SCOR model as recommendations if the diagnosis of certain processes by KPI shows a need for improvement.

- Associated software functionalities are identified which can enable the best practices for business process reengineering.

This SCOR model consists of four analytical stages leading to the implementation of an effective SCM strategy. The five distinct business processes-Plan, Source, Make, Deliver, and Return-are within the level 1 stage and should be further categorised into process categories depending on the activities involved. Hence, level 2 defines the core process categories that can be found in an actual and desired supply chain around an enterprise. For example, the source category includes source stocked products, source make-to-order (MTO) products, and source engineer-to-order (ETO) products (Table 1). These different types of channel activities derive from the three major customer demands. Making products to stock is challenging due to unknown demand quantities and procurement of raw materials, while making MTO and ETO products requires accurate demand forecasting and transparent market estimation.

$$
<<\text { Insert Figure } 1>>
$$


The model begins with an 'As-Is' (current status) analysis to capture the existing level 1 and level 2 processes while revealing geographical context, transportation costs, and trading relationships between the entities of the current supply chain. This requires the project team to canvas the business environment of an enterprise which should normally include two ties from the focal company (the centre of a supply chain, defined by Banerji and Sambharya, 1998 and Wang and Heng, 2002): that is, the customer's customer and the supplier's supplier. Figure 1 illustrates the linear format of applying the SCOR model which encompasses the business activities inside and outside the focal company and indicates the interactive relationships between the Delivery processes and the associated Make and Source processes from an understanding of aggregate demand to the fulfilment of each order.

Level 2 describes the information flows of forecasts/orders and the material flow with the types of goods produced and delivered by connecting the business processes involved (Figure 2 ). Because the SCOR model at level 1 and level 2 is a simplified version of the supply chain and enhances overall flexibility (Huang et al., 2005), level 3 represents the decomposition of level 2 processes in an interrelated way. For example, there are four level 3 components in P1 (the "Plan for Supply Chain") as shown in Figure 2:

- P1.1 - identify, prioritize, and aggregate production requirements;

- P1.2 - identify, assess, and aggregate supply chain resources;

- P1.3 - balance supply chain resources with supply chain requirements; and

- P1.4 - establish and communicate supply chain plans.

To accomplish the level 3 activities, the 'To-Be' (future) process model is developed to support the corporate strategies which should work within the new supply chain configuration at level 2. At this level, all SCOR processes are interconnected and running as an operation cycle of planning, execution, and enabling at a certain frequency. The supply chain components at level 4 are acting as the enabler with the work statements that are expected to be set up by the project team without standardized documents. The rationale for its exclusion is, although the SCOR model acknowledges the need for an effective implementation level (level 4) for SCM, this level which links specific requirements of competitive priorities for a particular supply chain setting lies outside of its scope. Eventually, the completed four levels become the guidelines for implementing supply chain management.

$$
<<\text { Insert Figure } 2>>
$$

The application of SCOR in supply chain planning has been receiving more and more attention. Choi et al. (2005) made use of a reference model (essentially the SCOR model) to illustrative how supply chain design processes can be integrated. That forms the basis to improve such design processes. More importantly, the model can enable and promote collaboration as the inconsistency between members of a supply chain can be solved through the standardised reference model, and hence the cycle time of product development could be decreased as advocated by the authors. However, there is a lack of application of the model to real-life situations. A similar concept was studied by Röder and Tibken (2006) who developed a model for modular production development, and proved their concept through a simulation study. In fact, the usefulness of SCOR can be further improved by computer-assisted tool for configuring supply chain model (Huang et al., 2005).

SCOR is not only useful in supply chain planning activities, the performance metrics as 
outlined in the SCOR model are also beneficial in measuring supply chain performance. For example, Wang et al. (2005) combined the benefits of Analytical Hierarchy Process (AHP) and the performance metric from the SCOR for evaluation and selection of suppliers. The metrics can help to cover the weaknesses of the AHP regarding the subjectivity in ranking different criteria. Similarly, Li et al. (2005) employed the SCOR performance metrics in measuring the supply chain performance (a construct in their model) in a questionnaire survey. In another empirical study, Swafford et al. (2006) used various components from SCOR to formulate a model for studying the antecedents of supply chain agility empirically.

The SCOR model has become a topical issue, attracting not only the interest of enterprises, but industrial associations and governments. In contrast to the emphasis in industry, there is a scarcity of academic literature regarding the application, adoption, benefits, and limitations of the SCOR model with few exceptions (see Lockamy III and McCormack (2004), Huang et al. (2005), and Wang et al. (2005)). Aspects of interest of the framework in the literature are discussed below.

\section{Supply Chain Planning and Business Process Reengineering}

According to the definition suggested by Hammer and Champy (1993, p. 32), BPR is "the fundamental rethinking and radical redesign of business processes to achieve dramatic improvements in critical contemporary measures of performance, such as cost, quality, service, and speed". Re-engineering involves the redesign of business processes by starting with the most valuable processes in a company in order to change the main performance indicators that make it possible to evaluate the satisfaction of customers' needs (Albizu et al., 2004). In the supply chain context, the literature provides significant insight into the role of planning in facilitating the effectiveness of SCM. For example, the studies on the planning of design and configuration of the supply chains to achieve corporate strategies (Vickery et al., 1999; Childerhouse and Towill, 2000; Croxton et al., 2001; Harland et al., 2001) which correspond to the ' $\mathrm{P}$ ' elements in levels 1 and 2 of the Supply Chain Operations Reference Model (Lockamy III and McCormack, 2004). Other areas in the literature include enterprise innovation, intercompany alliances, the control mechanism of performance measurements, and enabling supply chain information systems. The literature also suggests that effective use of supply chain information systems can particularly enhance channel competitiveness that includes advanced planning systems, enterprise research planning, Internet technologies, and corporate portals (D’Amours et al., 1999; Narasimhan and Kim, 2001).

Likewise, supply chain partnership is another focus of the literature that can help in collaborative activities across various functions and business boundaries (e.g., Lambert et al., 1996; Boddy et al., 1998). Such perspectives have been influenced y the study of strategic networks (e.g., Thorelli, 1986; Gulati, 1998) and yielded the subsequent supplier-buyer models of supply chain coordination (e.g., Barbarosoğlu, 2000). This literature also involves the development of strategic alliances (McCutcheon and Stuart, 2000), decision-making on outsourcing (Heriot and Kulkarni, 2001), setting up information-sharing parameters (Lamming et al., 2001), and defining the overall strategy to facilitate the integration activities for commonly shared parties in the supply chain setting (Frohlich and Westbrook, 2001) and links with organization structure, business processes, and performance measurement in logistics (Rodrigues et al., 2004). The literature in supply chain management corresponds to each of the five decision elements provided in the SCOR model and some of the observed studies have direct implications for the level 2 processes (Lockamy III and McCormack, 2004). The literature also provides cases adopting the Top-down approach which is similar to the concept of the SCOR model (e.g., Kumar, et al, 2008). 
Despite the extensive knowledge of SCM, only a few studies attempt to empirically link the limitations of BPR and SCOR practices to implementing SCM, especially in a global context. A recent example of integrated supply chain study by Rodrigues et al. (2004) mainly tests the supply chain behaviour of American companies. Although there is increasing attention paid to global supply chain planning, recent researchers have focussed on just a few specific areas. From the marketing discipline, Closs and Mollenkopf (2004) lay a framework for planning global supply chain management. Narasimhan and Mahapatra (2004) aggregate the academic research as a basis for formulas of decision-making models for global supply chain management that includes the estimation of buyer-suppler behaviour, sourcing strategies, market distribution, production systems, and facility layout. Likewise, Clark and Stoddard (1996), suggest a relationship model for presenting the interdependence of technological and process innovations in the interorganisational systems and supply chain trading relations in the retail industry. The above studies show that customer integration, technology and process planning, supply chain coordination, logistics management, performance control mechanisms, and supplier management are the dominant competencies associated with SCM process modification.

Although BPR was not originally developed for supply chain management (and SCOR as discussed before), research in BPR for supply chain management is still very important, partly because of the advance in information technology in the last decade (Gorla et al., 2007). For example, Clark and Hammond (1997) discussed the potential improvement in supply chain performance of reengineering the channel reordering process, Lin and Shaw (1998) studied various order fulfilment processes of a supply chain so that best re-engineering option can be figured out. Development of ERP is another crucial example of BPR which may significantly affect supply chains (Akkermans et al., 2003; Gattiker, 2007). Despite the importance of BRP to supply chain management, successful implementation of BRP (e.g. ERP) is not easy as the level of customisation is very high. Whilst ERP can further integrate supply chain activities, it is limited by its poor extensibility and inflexibility (Akkermans et al., 2003). Therefore, the reference process approach is advocated (Scheer and Habermann, 2000). For example, Changchien and Shen (2002) proposed a BPR framework for supply chain management by a core process analysis matrix, which consists of a number of performance measures. They tested the usefulness of the framework through a simulation study.

Nevertheless, only a few studies have attempted to empirically link BPR to the global supply chain level. Many of the studies focus on the identification of key processes in a multi-company setting. For example, Croxton et al. (2001) propose information architecture for improving channel visibility by combining eight major processes into strategic, interfacial, and operational levels for overhauling (i.e., customer service management, demand management, order fulfilment, manufacturing flow management, supplier relationship management, product development and commercialisation, and returns management). Lambert and Pohlen (2001) point out the problem with existing metrics used in evaluating supply chain activities is that most measures are associated with internal logistics operations as opposed to SCM. The supply chain must be viewed as one entity and any measurement systems should span the entire supply chain (Holmberg, 2000). Analysed with profit and loss statements, Lambert and Pohlen (2001) suggest the measure of market capital increase across different tiers of the supply chain as the requirement and basis of continual business process adjustments. Their viewpoint matches the content of the SCOR model, whose level 1 metrics (e.g., supply chain cost, supply chain responsiveness, etc.) are measured by aggregating the performance figures among operations of the entities within the supply chain. In this research, specific performance measurements were difficult to identify, although some information was implied by the existing measurement system used. 
The review of the literature suggests the following. First, the importance and necessity of BPR in supply chain planning is well established in the literature and warrants follow-up research. Second, literature published in this area corresponds to the major process elements provided in the SCOR model (Lockamy III and McCormack, 2004). Third, the activities illustrated in levels 1 and 2 can be used as a framework for conducting future SCM planning research, particularly the BRP stage because of the correspondence to SCOR process elements. Finally, there is a scarcity of empirical research clearly bridging the supply chain planning practice to process adjustments that is the methodology and theories of BRP in the supply chain context.

\section{The Research Purpose and Methodology}

This study presents an in-depth case of the necessary constituents for business process transition based on the four decision areas: KPI analysis, problem and grouping analysis, expectation of ownership, and expert opinions. The issues in this case involve adapting the SCOR model to implement supply chain management among trading partners and subsidiaries within the enterprise boundaries. Moreover, the supplementary tools for supply chain BPR in combining existing business processes, SCOR elements, and problem grouping/prioritizing are developed as a further contribution to the knowledge of supply chain research.

The primary consideration when selecting research methodologies is the research problem. The case study is an empirical inquiry used for investigating contemporary and ongoing phenomena in particular when the boundaries between phenomenon and context are not clearly evident (Yin, 2003). Case study research generally answers one or more questions which begin with 'why' or 'how'. In this study, we aim to:

(1) identify the applicability and limitations of the SCOR model in BPR and supply chain planning,

(2) suggest a new technique for BPR in SCM, and

(3) propose theoretical elements for the decisions in business process adjustments along the supply chain.

These research purposes are in line with the nature of an explorative case study, i.e. appropriate for generating or testing new theories and approaches (Eisenhardt, 1989; Yin, 2003).

A case study on the supply chain project of a multi-national fabric enterprise was carried out. There were 35 participants including the executives of the SCM project initiating company and its trading partners, the functional managers, project managers, and external consultants who were responsible at the highest level for the introduction and implementation of a global supply chain project. Our research teams also participated in this project to facilitate and advise on the progress of the BPR and global systems design phases. These interviews and meetings by face-to-face and internet channels took place at different locations across Taiwan and each of them had a duration of 120 to 180 minutes. In addition, we visited the facilities of some subsidiaries of the supply chain focal company to acquire on-site information about the manufacturing procedures, product envelopes, corporate strategies, and organization structure. Finally, the initiating company provided sufficient documentation about the magnitude of the project scope and the information on associated entities to demonstrate specific aspects of the experience and examine the SCOR model throughout this research. 
More specifically, data were collected by a series of interviews in a period of 3 weeks in the aforementioned companies, followed by a week for processing the data. This pattern was repeated for a number of cycles for about half a year until all 35 participants were interviewed. The collected data included the details of the processes involved, and those associated KPIs were presented later. After that, three months was spent in analysing the collected data and then drafting the reengineering program (detail analysis is reported in Section 5). Follow-up meetings and email communications were used to adjust the proposed BRP program. Finally, another three months were used to modify the supply chains and to shape up the global logistics enterprise system. In short, the whole project duration was about 1 year. Half of the year was used to collect data and the other half used to carry out the reengineering program. The method used is similar to action case study research.

\section{A Case Study of the Global Logistics Supply Chain Project}

\subsection{The context for BPR}

The Taiwanese company of the supply chain project, Company T, began in the early 1960s to produce artificial fabric such as bedding and batting fibres for industrial needs. Since then, Company $\mathrm{T}$ has increased its production and total sales volume to over US $\$ 100$ million. It adopted the strategy of reaching closer to the consumers' markets by integrating its supply chain. One of the initiatives involved was to acquire an American brand owner, Company A, in the furniture industry and similar actions are expected to take place in the European and Asian markets under the corporate vision of being a global brand owner.

The merger in 2004 created a need to unify all the areas of activity within the supply chain including the subsidiaries of Company $\mathrm{T}$ and to collaborate with the suppliers and the wholesalers. Thus, a strategic process redesign began that influenced every entity of Company T's consuming products supply chain and SCOR was chosen as the major referential model for this substantial task. The situation was as follows:

(1) It was known that within a few years the main wholesale customers would enter the emerging competitive areas such as Latin America, India, and China.

(2) Increasing market globalization created both the need to be competitive at the regional level and to position Company $\mathrm{T}$ in developing markets. The acquisition of Company $\mathrm{A}$ and the associated supply chain integration therefore becomes a template of its future global supply chain system.

(3) A certain level of business autonomy exists at each of the diversified manufacturing sites and it hinders the efficiency of central planning for dispatching orders and scheduling production.

(4) There was a short order-to-delivery request time of 14 days in the American market. More accurate forecasting is hence needed in order to reduce the manufacturing cost with a cheaper labour force by shifting a major portion of Company A's production to Asia because of the increased shipping time. Similar challenges are going to take place in other markets.

Company $\mathrm{T}$, historically having had a captive market in artificial fabric materials, therefore needed to centralise and coordinate the sales, manufacturing, sourcing, and distribution activities among the supply chain entities; in short, transforming the enterprise. The response comprised two phases as described below.

\subsection{Phase I: Project commencement and limitations encountered}

Company T merges with an US-based brand owner, Company A, and utilizes the reputation of 
Company A to approach wholesalers in the United States. In order to reduce the manufacturing costs, Company $\mathrm{T}$ decides to shift the manufacturing procedures from Factory 1 in the United States to Factory 2 in China with the exception of the final step of product assembly in the supply chain (Figure 3.1). The reason for leaving assembly procedures in Factory 1 is because shipping costs are calculated by product volume. Although the strategy sounds feasible; nonetheless, the subsequent longer lead-time of shipping and the potential higher risk of failure to deliver on time may occur since the products can only be made by make-to-order (MTO). The only solution is to have a global logistics planning centre which is responsible for coordinating the communication of forecasting, decision-making, and order execution in order to balance demand and supply in time. Hence, Company T decides to adopt global logistics information systems built in multiple sites with an enterprise portal as the communication platform.

Before the implementation of the global logistics information systems, Company $\mathrm{T}$ had used SCOR to investigate the 'As-Is' processes in this supply chain. Figure 3.2 shows that there are two major gaps in the control of supply chain. The decisions on order dispatching and demand forecasting have not been passed to Company $\mathrm{T}$ with the acquisition of Company A. However, it is not possible to take over the two functions immediately due to concern over generating tensions between the employees among the two enterprises despite the fact that Company $\mathrm{T}$ has the ownership of this supply chain.

Another difficulty that Company $\mathrm{T}$ has encountered relates to the lack of KPI information. It is necessary to find enough information regarding enterprise performance for the purpose of mapping KPI calculation with the activities of SCOR level 1 to level 3. Normally it is the basis for accurate KPI analysis in large companies, i.e. to equip ERP systems with historical data for aggregating calculation. In the current case, the ERP system is still a new tool for the employees of Company $\mathrm{T}$ and some departments feel reluctant to use it due to the incomplete customisation interfaces of ERP in Company $\mathrm{T}$.

\footnotetext{
"We are required to use the newly adopted ERP systems for business operations because it has been expected to increase corporate efficiency" the Project Manager of Company T, said. "However, many of our scattered production sites need much more information for preparing the material sourcing. Manufacturing orders printed from the ERP system fail to correspond to specific needs such as the required colour patterns and 'scrap factors' (i.e., the rate of the wasted part to a complete piece of raw material after the production processes) of each product component. With the rapid corporate expansion, ultimately, the material codes are not unified yet among our worldwide subsidiaries. Particularly, we do not have the relevant KPI information kept in the computer-based information systems that is required by the consultant team". (Interviewing Record: T120305)
}

\section{$<<$ Insert Figure $3>>$}

Moreover, many of the ERP modules of Company $\mathrm{T}$ have not yet been extended and integrated to its affiliate subsidiaries such as Factory 2 and Company A. In addition to the difficulty of getting cross-site KPI information, another concern appears during the project period. On the one hand, Company $\mathrm{T}$ requires a planning mechanism as the decision-base to deal with new or cancelled orders from the wholesalers; otherwise, these may cause critical losses if the M2 (MTO) process element in Factory 2 (Figure 3.2) is completed before a solution is found for cancelled orders. On the other hand, finished goods will not be delivered on time without the decision-base to reallocate production resources. Again, there is no specific suggestion in SCOR documents for addressing these situations. In other words, it is 
not possible to follow the typical analysing sequence of SCOR as a basis to develop global supply chain systems and enterprise portals in Company T's supply chain.

During the first project phase, we identified three types of limitations for applying SCOR in modifying current supply chain processes. These limitations have not been identified in the literature and are critical issues for the practical adoption of GLM systems. They involve graphical presentation, gap identification, and undefined business activities as summarised below:

The limitation of graphical presentation for intercompany flows

- SCOR can only present business flow between legal or geographical entities and not of a matrix organization structure or the concept of 'virtual enterprise'.

- SCOR is limited to the presentation of one single supply chain while most of the enterprises may be associated with multiple channels of markets and products.

\section{The limitation in identifying gaps}

- The KPI of SCOR is not always available in the target company T, particularly when it involves cross-site information.

- Even when KPI analysis is available, intangible problems cannot be identified such as cultural conflict or the uncertainty of supply chain coordination.

\section{Some essential activities not defined in the SCOR standard}

- Demand increases and reduction from order changes, e.g., emergent orders or order cancelling.

- The activities of collaborative design and customer relationships management are not defined in SCOR.

\subsection{Phase II: CESM technique, problem grouping, and process adjusting}

This phase began with a 'bottom-up' diagnosis of the situation carried out in collaboration with two consulting teams (including ours) that Company $\mathrm{T}$ had been working with. This diagnosis had several consequences. First, a detailed study of the company's problematic processes led to a list of 132 items categorised as institutional problems, organization structural problems, employee related problems, and problems of information systems/tools. The information on problem causes and effects was also collected through in-depth interviews with functional managers in Company $\mathrm{T}$, its subsidiaries, and Company A. As it is impossible to extract historical KPI information among sites, the aim of creating this problem list was to relate it to the diagnosis of the supply chain processes.

Secondly, top managers became conscious of the difficulties with implementing BPR along the supply chain and subsequently began to work on planning activities and participating in the problem grouping and prioritizing procedures. The 132 problems identified via interview of the key managers of the supply chain entities were then integrated into 15 major groups (See Appendix). In this phase, we proposed and adopted a technique to align the problems, business processes defined in SCOR, and the supply chain entities by an assimilative grouping analogy combining the Causes/Effects, the SCOR Standard, and Mutual Solution, namely "CESM".

As shown in Table 2, CESM is a composite of several components that includes problem grouping (PG) code, interview code, supply chain entities, PG category, and the SCOR process elements related to the problems. The steps of conducting CESM are described below.

Initially, in the PG code column we list the major problems grouped by similar causes/effects so that each of them corresponds to one or two of the four categories. The PG categories 
The last step of conducting CESM is to prioritize the problems in order to identify the possible sequence of BPR actions. Table 3 is the priority grid consisting of two dimensions: the degree of implementing difficulties and exigent levels estimated by the consultant teams and the top managers' expectations. We have adapted this prioritizing technique based on Bolstorff and Rosenbaum's (2003, p. 140) 'ease of implementation' grid for supply chain planning and the Kepner-Tregoe decision making model (Kepner and Tregoe, 1965). It is subjective to assign a degree of difficulty to a problem group based on the reliance on corporate resources, number of functions involved, and time expenditure. As can be seen in the table, all problem groups are set into each of the three divisions: must, want, and tentative. 'Must' represents the necessity of actions toward overcoming the problem groups in Company T's supply chain project; PG6, PG4, PG7, PG8, and PG5 were assigned in this division and ranked sequentially by the scale of exigent level. 'Want' represents the desire for the problems to be solved in this project; PG12, PG1, PG2/PG3, PG9, and PG11 were assigned in this division and ranked. BPR actions for problems PG13, PG15, and PG14 were considered to have 'tentative' business effects that were also ranked. All the problem groups were then set respectively with their corresponding level of difficulty.

$$
<<\text { Table } 3>>
$$

Finally, we have made decisions on the action ranking as shown at the bottom of Table 3 . The 
sequences of BPR actions for each problem group are seriated similarly to the opposite ranking of distance from each PG grid to the left-top origin point. They are PG $8 \rightarrow$ PG7 $\rightarrow$ PG5 $\rightarrow$ PG6 $\rightarrow$ PG4 in the 'Must' division, PG1 $\rightarrow$ PG3 $\rightarrow$ PG9 $\rightarrow$ PG12 $\rightarrow$ PG11 $\rightarrow$ PG12 in the 'Want' division, and PG13 $\rightarrow$ PG14 $\rightarrow$ PG15 in the 'Tentative' division. Notably, it is a result with the referential interval scales that come from human decisions on the degree of difficulties and the exigent levels. In addition, PG2 which had been intended to be solved in a subsequent project is removed from the prioritizing results. It has therefore left 10 PGs prioritized for actions within the current project as shown on the bottom of Table 3 .

\section{Limitations in SCOR and the four Decision Bases}

In this section, we reflect on what the study results suggest about the underlying limitations in SCOR planning decisions. Den Hengst and De Vreede (2004) suggest that the ultimate goal of a BPR project is provide to solutions agreed by stakeholders so as to improve organizational performance. However, we have observed from this case that the BPR project is also expected to lead the implementation of new enterprise systems and the establishment of new business sectors. The particular decision bases, while indicative of possible solutions, may therefore be symptoms of deeper factors in the current case and respective supply chain entities. In this case, there are at least four decision bases (depicted in Figure 4) including the KPI analysis suggested by the SCOR model. The rest are the problem/opportunities analysis, expectation/constraints, and the experts' opinions which can be amended in the SCOR model as explained below by a manager of Company $\mathrm{T}$ participating in this project.

"The SCOR model requires a current KPI analysis to enact the future processes.

However, due to insufficient information provided by our ERP systems, we have found it difficult to identify the gaps between As-Is and To-Be status. Particularly, there are no existing records for our new business of consumer products which are developed with this global supply chain project at the same time." (Interviewing Record:

T1180405)

KPI analysis: this approach follows the typical 'top-down' SCOR analytical processes and is relevant when most operation figures are recorded and updated regularly. Since it requires information across the boundaries of companies, the SCM adopters may often encounter difficulties. In the current case most channel participants are subsidiaries or joint ventures of a particular adopter because of unequal readiness of IT infrastructure or conflicts of management interests. It is likely that in many situations, there will be only a few of the business processes and functional tasks along the supply chain adjustable based on this decision.

Problem/opportunity analysis: when identifying the process 'gaps' by KPI information becomes difficult, it is possible to find out the existing problems and difficulties by interviewing the employees upstream and downstream of the supply chain. Contrary to the KPI analysis which starts from enacting the supply chain strategy and comparing existing performance and the targets, problem/opportunity analysis is rather a 'bottom-up' approach. It is suggested that the SCM project participants record feedback and then map it onto the different levels of SCOR processes. For instance, the KPI of 'daily sales receivable outstanding' in the Delivery element of SCOR level 2 is related to the process performance of the sales department. The same goal of identifying the SCM gaps can hence be achieved by directly finding problem/opportunity through individual interviews and observation. Following the CESM techniques, a project manager can further prioritize the actions of BPR toward the supply chain processes among the entities. 
Expectation/constraint: one of the key factors in implementing a SCM project is the participants' attitude and commitment to collaborative improvements. This will affect the information gathering for KPI and problem analyses and supply chain modification which is sometimes accompanied by the adjustment of existing benefits among channel members. The delivery routes, supply chain policies of pricing and return of goods, and requirement of forecasting between buyers-suppliers shown in this study may be altered after the SCM implementation. It is therefore necessary to find out the expectations/constraints of channel participants so as to avoid potential conflict among supply chain entities. Communication with the SCM initiator also helps to arrange the prioritization of problem groups within the project scope.

Another example seen in this case study shows that examining the demand management processes of the SCM initiator might lead to a tentative solution of implementing Collaborative Planning, Forecasting and Replenishment (CPFR) systems as suggested by the SCOR model. However, doing so might require the adoption of new IT infrastructure and lead to changing the existing demand management processes in some of the suppliers. Compromises are inevitable in order to make the transformation happen upstream and downstream of a supply chain. Several considerable issues are noted when identifying the expectations and constraints of the supply chain stakeholders:

- The enterprise as a participant in a business ecosystem and supply network;

- The cluster of companies which gradually evolves as a group-the coevolution effects;

- The gradual development of shared vision — centred around a product or product group; and

- The role of clusters in competitiveness.

The experts' experiences/communication: the last decision base for the supply chain transformation is to adopt the experts' opinions from the third party. A SCM project covers the areas of channel collaboration in material management, production planning, sales/distribution, quality control, asset management, and cost controlling and requires the knowledge of business process enablers such as the adoption of information systems. Acquiring the experts' opinions is vital to the success of any SCM project not only because of the needs for the above expertise but also in the pre-selection adoption methods, business process design, training, and customized IT systems. This means that companies are likely to need assistance from the consulting companies to enact the appropriate adoption methods and learn from others' experiences. Nevertheless, the SCM project owners have to interact with outside consultants who are not always familiar with the 'know-how' of a particular industrial context.

In short, the transformation/BPR of existing supply chain processes and structure relies on identifying the gaps and opportunities for improvement. Both 'top-down' and 'bottom-up' approaches are keys to success of supply chain configuration. Moreover, it is necessary to discreetly survey the stakeholders' expectations from the standpoints of various supply chain entities in order to ensure substantial benefits, and to understand both successful and unsuccessful cases through the experience of experts from the third party.

\section{Conclusion}


As stated above, SCM plays a role in influencing economic behaviour by the way business processes are managed. This in itself is certainly a very significant point, as it influences the costs of inventory holding, goods delivery, and manufacturing processes. It particularly affects the performance in customer fulfilment and cash-to-cash cycling which is vital for enterprise survival (Garrison and Noreen, 2003). Achieving effectiveness of SCM does not only rely on process tuning but also the just-in-time communication and decision-making through the enablers as performance measurement and information systems. Despite its importance, however, there is not much literature on the implementing framework and most of the existing reports are individual case studies (Croom et al., 2000).

The SCOR model has been the most widely adopted standard and may be the only one for the analysis of SCM implementation. The model has been modified several times since its first publication by the Supply Chain Council in 1996. It should be noted that it is not a comprehensive framework for implementing a SCM project but merely a referential tool for assigning business processes and associated factors of performance measures. It may actually be counterproductive to proceed without considering stakeholders' values/expectations and including the mutually owned processes in performance measurement. Therefore, we have addressed its weaknesses by discussing the supply chain configuration and transformation and the implementing procedures, using a case study in order to identify the limitations of the SCOR model, suggesting a CESM technique to supplement it, and proposing the decision-making basis for BPR in the supply chain context. As a matter of fact, a number of other factors, such as cultural issues, organisational issues, and the behavioural issues (which are indeed a chemistry of people involved and the case scenario) could influence the efficacy of the SCOR model. A multi-disciplinary approach may be adopted in future study to further analysis the moderating effects of the aforementioned factors. This research is limited to an action project while future studies are suggested to apply or adapt the proposed technique in various industries and projects, particularly a set of structural case studies to generalise the applicability.

Future multi-disciplinary research is also required to test the proposed techniques and the four decision-making bases in business settings in different industries and regions. Other barriers and limitations to SCM implementation and how they should be overcome need to be further identified. These may consist of increases and reductions in demand from order changes, e.g., emergent orders or order cancelling and the calculation of KPI for non-financial figures from the operation activities. To the extent that similar difficulties and solutions are identified in various supply chain contexts, it is possible that a refined framework can be developed for practitioners. Finally, progress should be tracked over time to demonstrate the long-term benefits derived from implementing SCM based on such a framework.

\section{References}

Akkermans, H. A., Bogerd, P., Yücesan, E., and Van Wassenhove, L. N., 2003, "The impact of ERP on supply chain management: Exploratory findings from a European Delphi study", European Journal of Operational Research, Vol. 146, No. 2, pp. 284-301.

Albizu, E., Olazaran, M., and Simon, K., 2004, "BPR and Change Management: A Case Study of a Large Spanish Electricity Company", International Journal of Innovation Management, Vol. 8, No. 4, pp. 355-379.

Banerji, K. and Sambharya, R.B., 1998, "Effect of Network Organization on Alliance Formation: A Study of the Japanese Automobile Ancillary Industry", Journal of International Management, Vol. 4, No. 1, pp. 41-57.

Barbarosoğlu, G., 2000, “An Integrated Supply-Buyer Model for Improving Supply Chain 
Coordination", Production Planning \& Control, Vol. 11, No. 8, pp. 732-741.

Boddy, D., Cahill, C., Charles, M., Fraser-Kraus, H., and Macbeth, D., 1998, "Success and Failure in Implementing Supply Chain Partner: an Empirical Study", European Journal of Purchasing \& Supply Management, Vol. 4, pp. 143-151.

Bolstorff, P. and Rosenbaum, R.G., 2003, Supply Chain Excellence - A Handbook for Dramatic Improvement Using the SCOR Model. New York: American Management Association.

Chan, H. K., and Chan, F. T. S., 2009, "Effect of Information Sharing in Supply Chains with Flexibility", International Journal of Production Research, Vo.1. 47, No. 1, pp. 213-232.

Changchien, S. W., and Shen, H. -Y., 2002, "Supply chain reengineering using a core process analysis matrix and object-oriented simulation”, Information \& Management, Vol. 39,

Chen, C.-K. and Tsai, C. H., 2998, "Developing a process re-engineering-oriented organizational change exploratory simulation system (PROCESS)", International Journal of Production Research, Vol. 46, No. 16, pp. 4463-4482.

Childerhouse, P. and Towill, D., 2000, "Engineering Supply Chains to Match Customer Requirements", Logistics Information Management, Vol. 13, No. 6, pp. 337-345.

Choi, Y., Kim, K., and Kim, C., 2005, "A design chain collaboration framework using reference models", International Journal of Advanced Manufacturing Technology, Vol. 26, No. 1-2, pp. 183-190.

Clark, T. H., and Hammond, J. H., 1997, "Reengineering channel reordering processes to improve total supply-chain performance", Production and Operations Management, Vol. 6, No. 3, pp. 248-265.

Clark, T. H. and Stoddard, D. B., 1996, "Interorganizational Business Process Redesign: Merging Technological and Process Innovation", Journal of Management Information Systems, Vol. 13 Issue 2, p9-28, 20p, 3 diagrams.

Closs, D.J. and Mollenkopf, D.A., 2004, "A Global Supply Chain Framework", Industrial Marketing Management, Vol. 33, pp. 37- 44.

Croom, S., Romano, P., and Giannakis, M., 2000, "Supply Chain Management an Analytical Framework for Critical Literature Review", European Journal of Purchasing \& Supply Management, Vol. 6, pp. 67-83.

Croxton, K.L., García-Dastugue, S.J., Lambert, D.M., and Rogers, D.S., 2001, "The Supply Chain Management Processes", International Journal of Logistics Management, Vol. 12, No. 2, pp.13-34.

D'Amours, S., Montreuil, B., Lefrancois, P., and Soumis, F., 1999, "Networked Manufacturing: The Impact of Information Sharing", International Journal of Production Economics, Vol. 58, No. 1, pp. 63-79.

Davenport, T.H., and Short, J.E., 1990, "The New Industrial Engineering: Information Technology and Business Process Redesign." Sloan Management Review, Vol. 32, pp. 11-27.

Eisenhardt, K.M., 1989, "Building Theory from Case Study Research", Academy of Management Review, Vol. 14, No. 4, pp. 532-550.

Frohlich, M.T. and Westbrook, R., 2001, "Arcs of Integration: An International Study of Supply Chain Strategies", Journal of Operations Management, Vol. 19, No. 2, pp. 185-200.

Grant, G.G., 2003, "Strategic Alignment and Enterprises Systems Implementation: The Case of Metalco", Journal of Information Technology, Vol. 18, pp. 159-185.

Gulati, R., 1998, “Alliances and Networks”, Strategic Management Journal, Vol. 19, No. 4, pp. 293-317.

Gunasekaran, A. and Kobu, B., 2002 "Modelling and analysis of business process reengineering", International Journal of Production Research, Vol. 40, No. 11, pp. 2521-2546. 
Hammer, M. and Champy, J., 1993, Reengineering the Corporation. A Manifesto for Business Revolution. London: Nicholas Brealey Publishing.

Hales, H.L. and Savoie, B.J., 1994, "Building a Foundation for Successful Business Process Reengineering”, Industrial Engineering, Vol. 26, No. 90, pp. 17-19.

Harland, C.M., Lamming, R.C., Zheng, J., and Johnsen, T.E., 2001, “A Taxonomy of Supply Networks", Journal of Supply Chain Management, Vol. 37, No. 4, pp. 20-27.

Den Hengst, Marielle and De Vreede, Gert-Jan, 2004, "Collaborative Business Engineering: A Decade of Lessons from the Field", Journal of Management Information Systems, Vol. 20, Issue 4, p85-113.

Gattiker, T. F., 2007, Enterprise resource planning (ERP) systems and the manufacturing-marketing interface: an information-processing theory view, International Journal of Production Research, Vol. 45, No. 13, pp. 2895-2917.

Gorla, N., Chinta, R., and Chu, T. W., 2007, "An enhanced business process re-engineering model for supply chain management and a case study", Journal of Information Technology Case and Application Research, Vol. 9, No. 2, pp. 5-27.

Heriot, K.C. and Kulkarni, S.P., 2001, "The Use of Intermediate Sourcing Strategies", Journal of Supply Chain Management, Vol. 37, No. 1, pp. 18-26.

Hewitt, F., 1995, "Business Process Innovation in the mid-1990s", Integrated Manufacturing Systems, Vol. 6, No. 2, pp. 18-26.

Holmberg, S., 2000, "A Systems Perspective on Supply Chain Measurements", International Journal of Physical Distribution and Logistics Management, Vol. 30, No. 10, pp. 847-868.

Huang, S.H., Sheoran, S.K., and Keskar, H., 2005, "Computer-assisted Supply Chain Configuration Based on Supply Chain Operations Reference (SCOR) Model", Computers \& Industrial Engineering, Vol. 48, pp. 377-394.

Kaplan, R.S. and Norton, D.P., 1996, Translating Strategy into Action: The Balanced Scorecard. Boston: Harvard Business School Press.

Kepner, C.H. and Tregoe, B.B., 1965, The Rational Manager: A Systematic Approach to Problem Solving and Decision Making. New York: McGraw-Hill.

Kumar, A., Ozdamar, L., and Zhang, C.N., 2008, "Supply Chain Redesign in the Healthcare Industry of Singapore", Supply Chain Management: An International Journal, Vol. 13, No. 2, pp. 95-103.

Lambert, D.M., Emmelhainz, M.A., and Gardner, J.T., 1996, "Developing and Implementing Supply Chain Partnerships", International Journal of Logistics Management, Vol. 7, No. 2, pp. 1-17.

Lambert, D.M. and Pohlen, T.L., 2001, "Supply Chain Metrics", International Journal of Logistics Management, Vol. 12, Issue 1, 1-19.

Lamming, R.C., Caldwell, N.D., Harrison, D.A., and Phillips, W., 2001, "Transparency in Supply Relationships: Concept and Practice", Journal of Supply Chain Management, Vol. 37, No. 4, pp. 4-10.

Li, S., Rao, S. S., Ragu-Nathan, T. S., and Ragu-Nathan, B., 2005 "Development and validation of a measurement instrument for studying supply chain management practices", Journal of Operations Management, Vol. 23, No. 6, pp. 618-641.

Lin, F. -R., and Shaw, M. J., 1998, "Reengineering the Order Fulfillment Process in Supply Chain Networks", International Journal of Flexible Manufacturing Systems, Vol. 10, No. 3, pp. 197-229.

Lockamy III, A., and McCormack, K., 2004, "Linking SCOR Planning Practices to Supply Chain Performance, An Explorative Study", International Journal of Operations \& Production Management, Vol. 24, No. 12, pp. 1192-1218.

Macbeth, D.K. and Ferguson, N., 1994, Partnership Sourcing: An Integrated Supply Chain Management Approach. London: Financial Times/Pitman Publishing.

McCutcheon, D. and Stuart, F.I., 2000, "Issues in the Choice of Supplier Alliance Partners", Journal of Operations Management, Vol. 29, No. 1, pp. 65-83. 
Narasimhan, R. and Kim, S.W., 2001, "Information System Utilization Strategy for Supply Chain Integration”, Journal of Business Logistics, Vol. 22, No. 2, pp. 51-76.

Narasimhan, R. and Mahapatra, S., 2004, "Decision Models in Global Supply Chain Management", Industrial Marketing Management, Vol. 33, pp. 21-27.

Noreen, E. W. and Garrison, R. H., 2003, Managerial Accounting, New York: McGraw-Hill College.

Pramatari, K., 2007, "Collaborative Supply Chain Practices and Evolving Technological Approaches", Supply Chain Management: An International Journal, Vol. 12, No. 3, pp. 210-220.

Patnayakuni, Ravi, Rai, Arun, Seth, Nainika, 2006., "Relational Antecedents of Information Flow Integration for Supply Chain Coordination”, Journal of Management Information Systems, Vol. 23, Issue 1, p13-49.

Rodrigues, A.M., Stank, T.P., and Lynch, D.F., 2004, "Linking Strategy, Structure, Process, and Performance in Integrated Logistics", Journal of Business Logistics, Vol. 25, No. 2, pp. 65-94.

Röder, A., and Tibken, B., 2006, "A methodology for modeling inter-company supply chains and for evaluating a method of integrated product and process documentation", European Journal of Operational Research, Vol. 169, No. 3, pp. 1010-1029.

Scheer A. -W., and Habermann, F., 2000, "Making ERP a success", Communications of the ACM, Vol. 43, No. 4, pp. 57-61.

Supply Chain Council, 2005, Supply Chain Operations Reference Model: Overview of SCOR version 7.0. Washington: Supply Chain Council.

Swafford, P. M., Ghosh, S., Murthy, N., 2006, "The antecedents of supply chain agility of a firm: Scale development and model testing", Journal of Operations Management, Vol. 24, No. 2, pp. 170-188.

Thorelli, H.B., 1986, "Networks: Between Markets and Hierarchies", Strategic Management Journal, Vol. 17, pp. 37-51.

Vernadat, F. B., 1996, Enterprise Modeling and Integration: Principles and Applications. UK, Chapman \& Hall.

Vickery, S., Calantone, R. and Droge, C., 1999, "Supply Chain Flexibility: An Empirical Study", Journal of Supply Chain Management, Vol. 35, No. 3, pp. 16-28.

Wang, G., Huang, S. H., and Dismukes, J. P., 2005, "Manufacturing supply chain design and evaluation", International Journal of Advanced Manufacturing Technology, Vol. 25, No. 1-2, pp. 93-100.

Wang, W.Y.C. and Heng, M.S.H., 2002, "Boundaries of Business Network in Supply Chain: Overcoming SMEs Barriers in Implementing Business-to-Business Integration", the 4th International Conference on Electronic Commerce, Hong Kong.

Wang, W.Y.C., Ho, M.S.C, and Chau, P.Y.K., 2005, "A Process Oriented Methodology for the Supply Chain Analysis of Implementing Global Logistics Information System", Proceedings of the 2nd International Conference on Innovations in Information Technology, 26-28 September, 2005, Dubai, UAE.

Yin, R.K., 2003, Case Study Research - Design and Methods, Third Edition. New York: Sage. 


\section{Appendix: The Prioritized Problem Groups (two pages)}

\begin{tabular}{|c|c|c|}
\hline GP Code & Category & Cause/Effect \\
\hline PG8 & Institution & $\begin{array}{l}\text { There is a no unified rule for materials/item coding } \\
\text { Scrap factors are not maintained well among the subsidiaries }\end{array}$ \\
\hline PG7 & Systems Tool & $\begin{array}{l}\text { Lack of an unified platform to link multi-site systems } \\
\text { ERPs are not installed in some manufacturing sites } \\
\text { Lack of staff training for adapting new information systems }\end{array}$ \\
\hline PG5 & Institution & $\begin{array}{l}\text { Part of the order information is concealed by the downstream } \\
\text { partners/subsidiaries that it leads to the insufficient information for supply } \\
\text { planning. It is also due to the lack of standardised sales procedure enacted by the } \\
\text { head office of Company T. }\end{array}$ \\
\hline PG6 & $\begin{array}{l}\text { Organization } \\
\text { Structure/HR }\end{array}$ & $\begin{array}{l}\text { Organization Structure is unclear in the newly merged company. It additionally } \\
\text { results in the decision-making of order dispatching and supply planning among } \\
\text { the subsidiary being unconnected or lacking concern about the enterprise-wide } \\
\text { supply chain. New demand planning processes need to be invoked and designed. }\end{array}$ \\
\hline PG4 & $\begin{array}{l}\text { Business Process/ } \\
\text { System Tool }\end{array}$ & $\begin{array}{l}\text { There is a scarcity of coordinating processes and mechanisms among } \\
\text { manufacturing sites and most communication is still maintained by the human } \\
\text { labour force. }\end{array}$ \\
\hline PG1 & Institution & $\begin{array}{l}\text { No standardized estimation method for cost calculation, particularly the } \\
\text { Just-in-Time information for product quoting by the sales department. }\end{array}$ \\
\hline PG3 & $\begin{array}{l}\text { Business Process/ } \\
\text { System Tool }\end{array}$ & $\begin{array}{l}\text { The information of consumption of critical materials per product unit is not } \\
\text { controlled by the head office and the subsidiaries do not share such information } \\
\text { with each other. A centralised database which records all Bills of Materials } \\
\text { (BOM) is needed. }\end{array}$ \\
\hline PG9 & $\begin{array}{l}\text { Institution \& } \\
\text { Organization } \\
\text { Structure/HR }\end{array}$ & $\begin{array}{l}\text { Overseas sales subsidiaries do not have sufficient quality control (QC) } \\
\text { information, especially the specifications of products which have not been } \\
\text { monitored and maintained by some manufacturing sites. It leads to the } \\
\text { unnecessary return of goods. Such information should be controlled by both the } \\
\text { outbound logistics department of the manufacturing sites and the inbound } \\
\text { logistics department of sales subsidiaries. }\end{array}$ \\
\hline PG12 & Institution & $\begin{array}{l}\text { Production and inventory information is not exchanged among the } \\
\text { manufacturing sites that it causes the failure of resource sharing and fewer } \\
\text { opportunities for seeking alternative materials when an emergent order occurs. }\end{array}$ \\
\hline PG11 & Institution & $\begin{array}{l}\text { Sales subsidiaries lack market information for demand forecasting. It affects } \\
\text { the long-term decision basis for product design, marketing strategy, capacity } \\
\text { planning, and procurement. department }\end{array}$ \\
\hline PG13 & $\begin{array}{l}\text { Institution \& } \\
\text { Business Process }\end{array}$ & $\begin{array}{l}\text { Redundant monthly procurement activities delay the arrival of raw materials } \\
\text { and affect the execution of production planning. }\end{array}$ \\
\hline
\end{tabular}

Continue to Next Page. 
NB: the descriptions are simplified and adjusted for this publication. 


\section{List of Figures}

Figure 1. Applying the SCOR model for supply chain linkage

Figure 2. The 'Top-Down' approach in implementing the SCOR model

Figure 3. The 'As-Is' flows of SCOR levels $1 \& 2$ in the current supply chain

Figure 4. Components for BPR in the Supply Chain Context

\section{List of Tables}

Table 1. Supply chain activities based on SCOR levels 1 and 2

Table 2. CESM Table for Supply Chain Process Diagnosis

Table 3. Prioritizing Problem Groups 


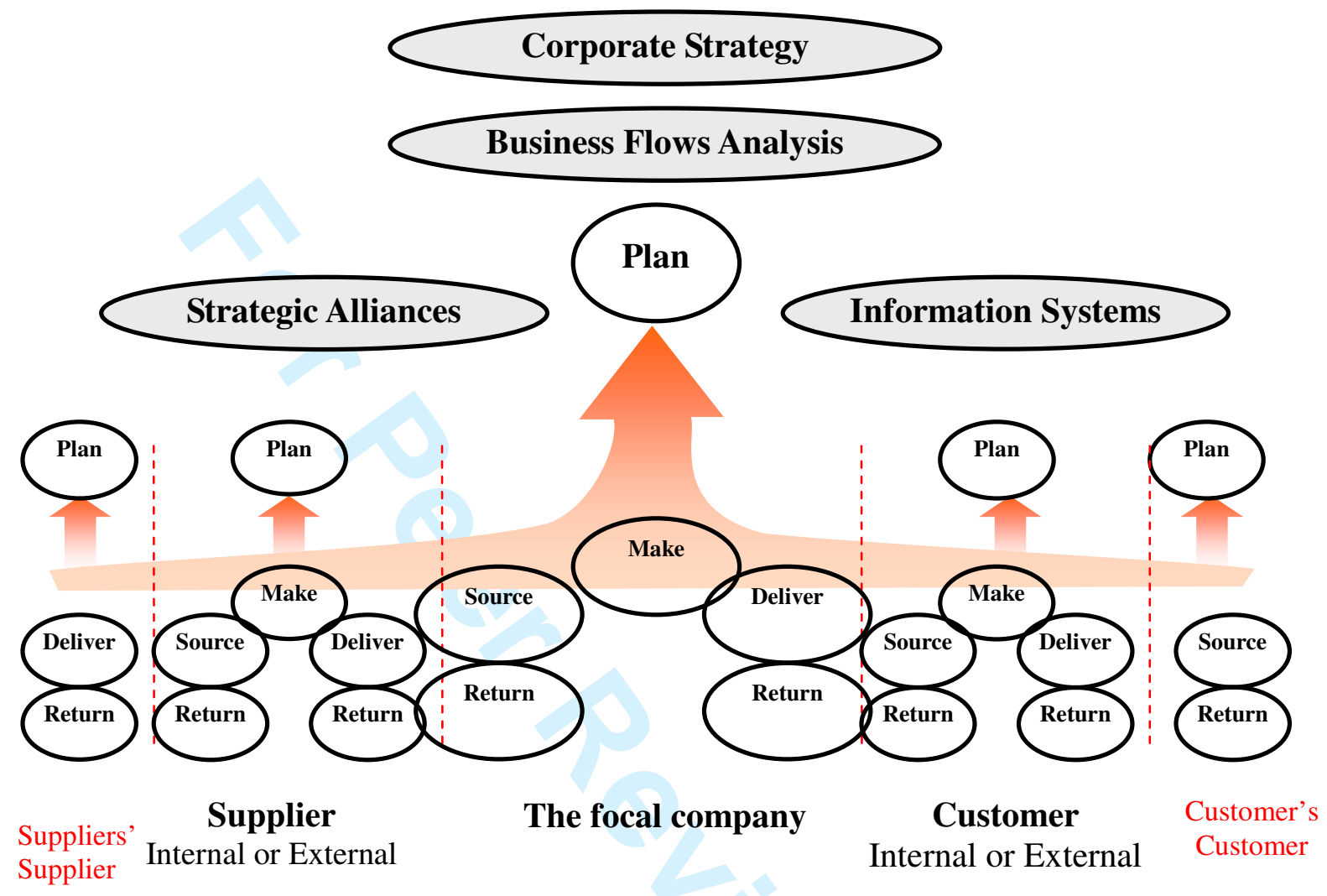

Figure 1. Applying the SCOR model for supply chain linkage

Source: Adapted from Supply Chain Operations Reference Model Version 7, Supply Chain Council, 2005 


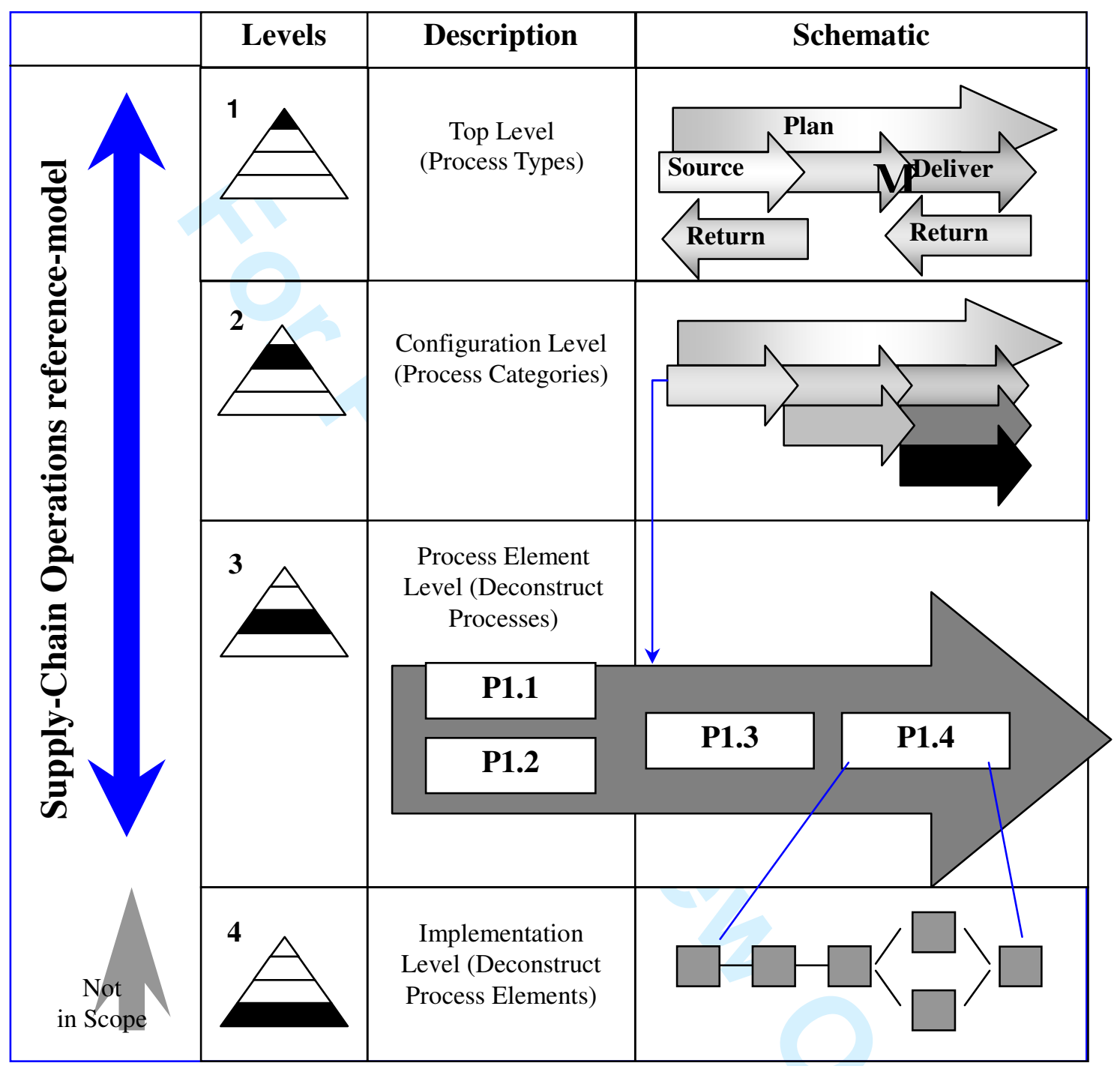

Figure 2. The 'Top-Down' approach in implementing the SCOR model

Source: Supply Chain Council SCOR version 7.0 
Figure 3(a) The materials flows (in level 1)

$$
\text { Supplier } 1
$$

Factory 1 (owned by Company A, US)

Wholesalers (US)

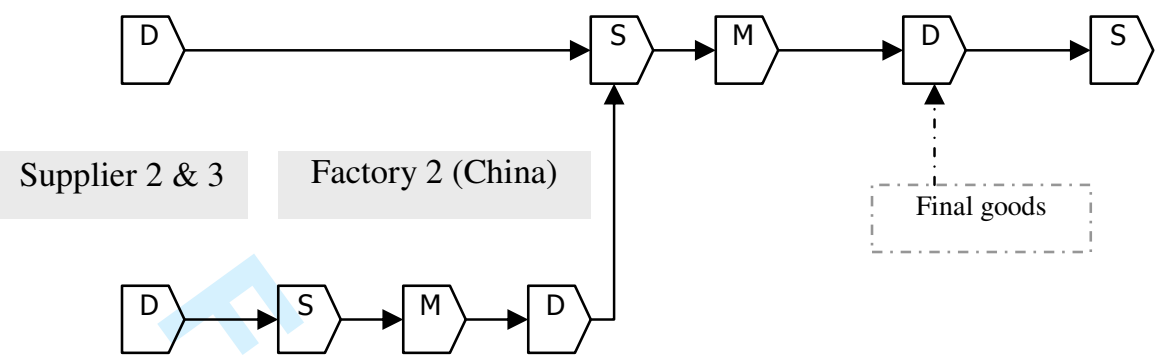

Figure 3(b) The information flows (in level 2)

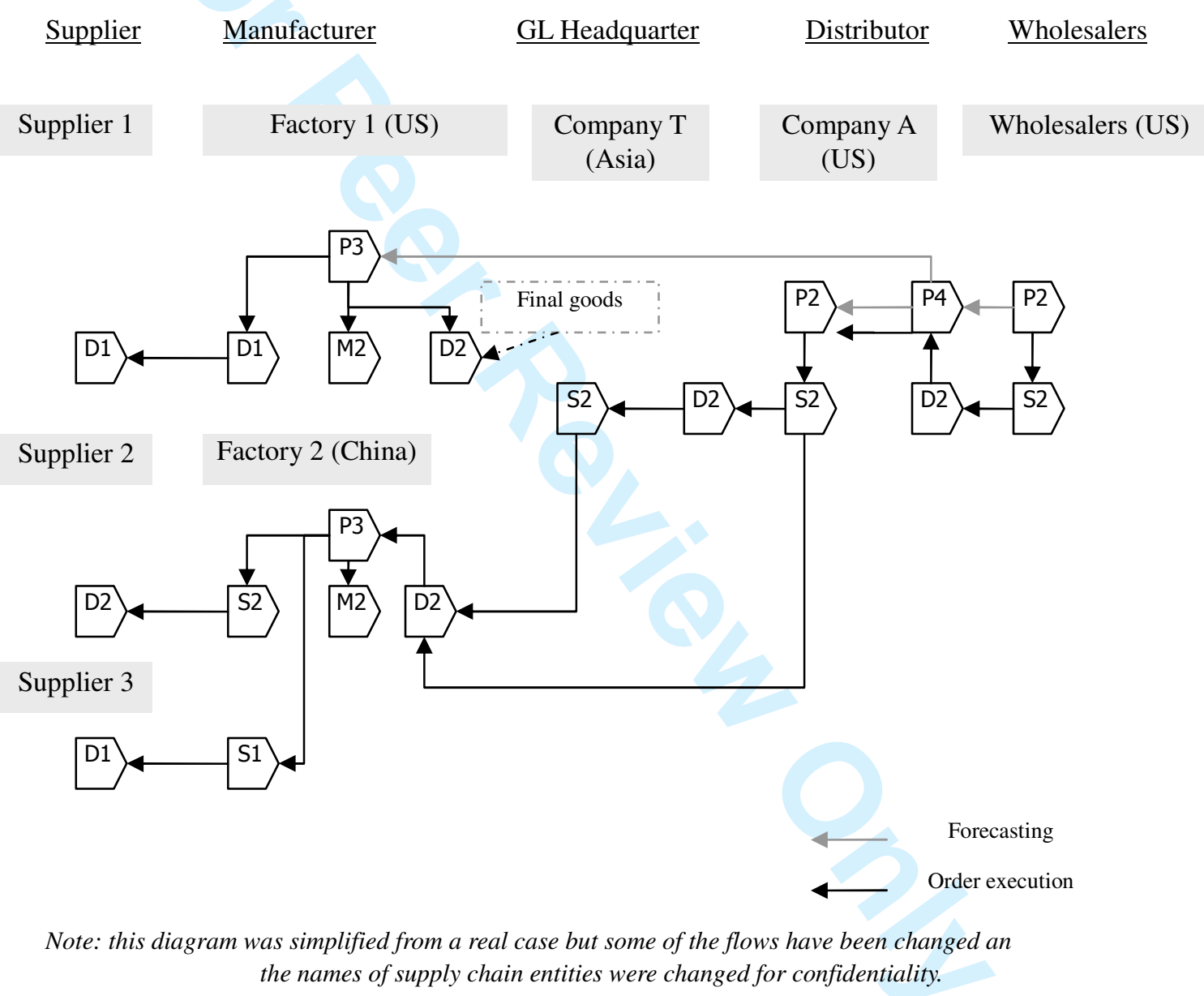

Figure 3. The 'As-Is' flows of SCOR levels $1 \& 2$ in the current supply chain 

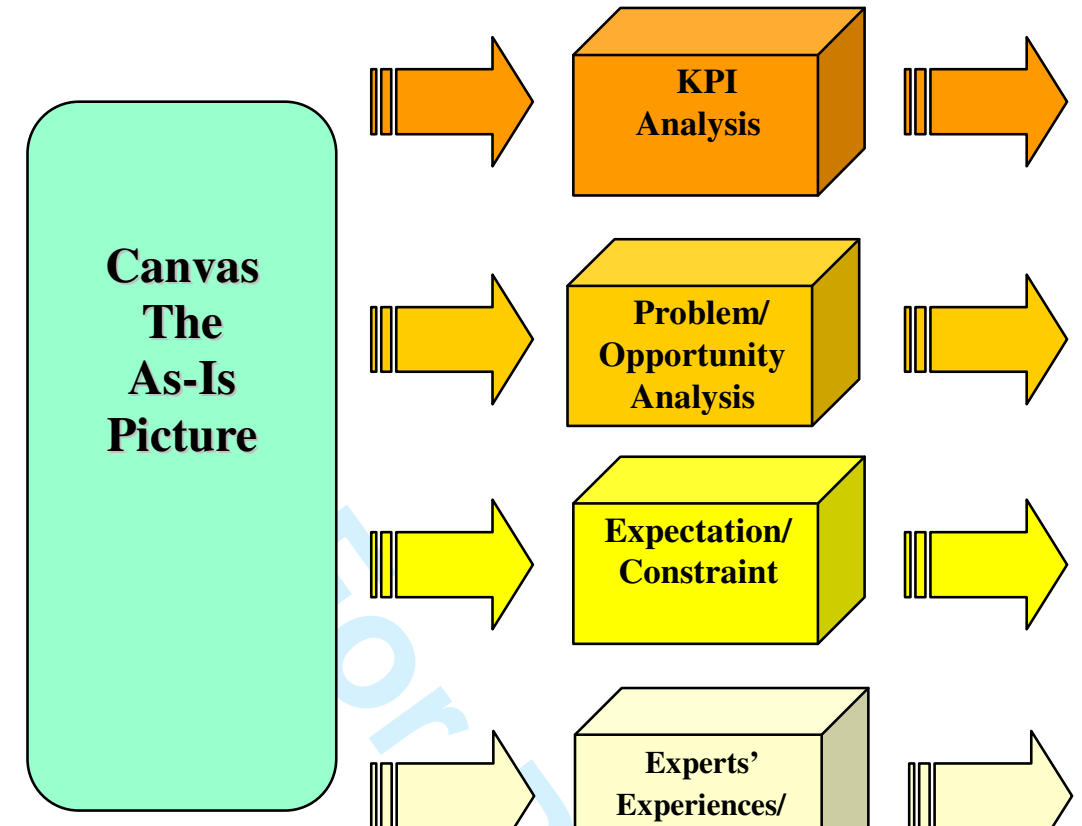

Designing

The To-Be

Processes, Organization

Structure, and Performance Control
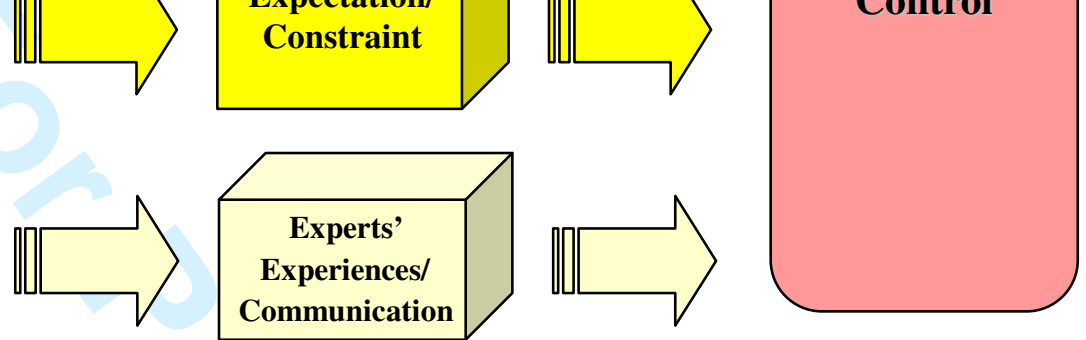

Figure 4. Components for BPR in the Supply Chain Context 
Table 1. Supply chain activities based on SCOR levels 1 and 2

\begin{tabular}{|c|c|c|c|c|c|c|c|}
\hline Plan & & Sour & & Make & & Deli & er \\
\hline $\mathrm{P} 1$ & Plan Supply Chain & S1 & Source Stocked & M1 & Make-to-Stock & D1 & Deliver Stocked \\
\hline P2 & Plan Source & & Product & & & & Product \\
\hline & & S2 & Source MTO Product & M2 & Make-to-Order & D2 & Deliver MTO Product \\
\hline $\mathrm{P} 3$ & Plan Make & & & & & & \\
\hline P4 & Plan Deliver & S3 & Source ETO Product & M3 & Engineering-to-Order & D3 & Deliver ETO Product \\
\hline Sour & ce Return & & & Delive & er Return & & \\
\hline SR1 & SR2 & & SR3 & DR1 & DR2 & & DR3 \\
\hline R1: & Return Defective Pr & roduct & R2: Return M & RO Pro & duct & : Retu & rn Excess Product \\
\hline
\end{tabular}


Table 2. CESM Table for Supply Chain Process Diagnosis

\begin{tabular}{|c|c|c|c|c|c|c|c|c|c|c|c|c|c|}
\hline \multirow[b]{2}{*}{$\begin{array}{l}\text { PG } \\
\text { Code }\end{array}$} & \multirow{2}{*}{$\begin{array}{l}\text { Channel } \\
\text { Entities } \\
\text { Interviem } \\
\text { Code }\end{array}$} & \multicolumn{2}{|c|}{$\begin{array}{c}3^{\text {rd }} \text { Tier } \\
\text { Suppliers } \\
\end{array}$} & \multicolumn{2}{|c|}{$\begin{array}{c}2^{\text {nd }} \text { Tier } \\
\text { Suppliers }\end{array}$} & \multicolumn{2}{|c|}{$\mathbf{1}^{\text {st }}$ Tier Supplier } & \multirow[b]{2}{*}{$\begin{array}{c}\text { Focal } \\
\text { Company }\end{array}$} & \multicolumn{2}{|c|}{$1^{\text {st }}$ Tier Customers } & \multicolumn{2}{|c|}{$\begin{array}{c}2^{\text {ndd }} \text { Tier } \\
\text { Customers }\end{array}$} & \multirow[b]{2}{*}{ PG Cat' } \\
\hline & & 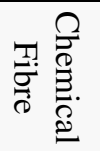 & 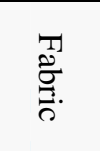 & w & 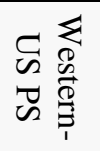 & 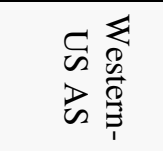 & 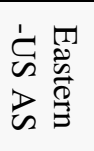 & & 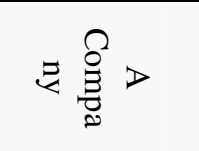 & $\underset{\substack{0 \\
\frac{8}{9}}}{0}$ & 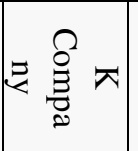 & 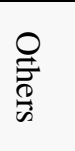 & \\
\hline PG1 & $\mathrm{A} 1, \mathrm{~A} 7, \mathrm{~B} 3, \mathrm{~B} 13$ & & D2c & $\mathrm{D} 2 \mathrm{a}$ & & & & P2a,D2e,D2a & & & & & Institution \\
\hline PG2 & $\begin{array}{c}\mathrm{A} 2 \mathrm{a}, \mathrm{A} 6, \mathrm{~A} 10, \mathrm{~A} 1 \\
2, \mathrm{E} 19\end{array}$ & & $\begin{array}{l}\mathrm{P} 4 \mathrm{c}, \\
\mathrm{D} 2 \mathrm{c} \\
\mathrm{P} 3 \mathrm{c}\end{array}$ & S2c & & & & $\begin{array}{c}\mathbf{P} 1 \mathbf{c}, \mathbf{P} 2 \mathbf{a}, \mathrm{P} 2 \mathrm{c}, \mathrm{S} 2 \\
\mathrm{c}\end{array}$ & P1c & & & & $\begin{array}{l}\text { Company } \\
\text { Structure } \\
\text { /Employee }\end{array}$ \\
\hline PG3 & $\mathrm{A} 2 \mathrm{~b}$ & & $\mathrm{D} 2 \mathrm{c}$ & $\mathrm{P} 3 \mathrm{c}$ & 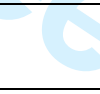 & P & & P1c, D2a & & & & & $\begin{array}{c}\text { Business Process/ } \\
\text { System Tool }\end{array}$ \\
\hline PG4 & $\begin{array}{c}\text { A3,B5,B9,B10, } \\
\text { B11, } \\
\text { E10, E11,E15,C4 }\end{array}$ & $\mathrm{P} 3 \mathrm{~b}$ & $\mathrm{P} 3 \mathrm{c}$ & $\mathrm{P} 3 \mathrm{a}$ & P3f & P3a & P3a & P1a,P2a, ERP & $\mathrm{P} 4 \mathrm{~g}$ & & & & $\begin{array}{c}\text { Business Process/ } \\
\text { System Tool }\end{array}$ \\
\hline PG5 & $\mathrm{A} 4$ & & & & & & 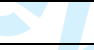 & 28 & D2g,S2a & & & & Institution \\
\hline PG6 & $\begin{array}{c}\text { A5a,A5b,B14, } \\
\text { E7 }\end{array}$ & & & & & & & P1a,P4g & P1a,P4g,EP & & & & $\begin{array}{l}\text { Company } \\
\text { Structure } \\
\text { /Employee }\end{array}$ \\
\hline PG7 & $\begin{array}{c}\text { A8,A9b,A13,D8, } \\
\text { D12b.c.d.e,C8b. } \\
\text { d }\end{array}$ & & & & & & & ERP & & & & & System Tool \\
\hline PG8 & A9a,B7, D16 & & & $\begin{array}{l}\text { P3a, } \\
\text { M2 }\end{array}$ & $\begin{array}{l}\text { P3f, } \\
\text { M2 }\end{array}$ & P3a,M2 & $\begin{array}{l}\text { P3a, } \\
\text { M2 }\end{array}$ & ERP & $\mathrm{P} 2 \mathrm{a}$ & & & & Institution \\
\hline PG9 & A11,E1 & & $\mathrm{D} 2 \mathrm{c}$ & $\begin{array}{l}\mathrm{S} 2 \mathrm{c}, \mathrm{D} \\
2 \mathrm{a}\end{array}$ & & $\mathrm{S} 2 \mathrm{a}$ & $\mathbf{S 2 a}$ & & S2a & & & & $\begin{array}{l}\text { Institution/ } \\
\text { Company } \\
\text { Structure } \\
\text { /Employee }\end{array}$ \\
\hline$\ldots$ & $\ldots$ & $\ldots$ & $\ldots$ & $\ldots$ & $\ldots$ & $\ldots$ & $\ldots$ & $\ldots$ & $\ldots$ & $\ldots$ & $\ldots$ & $\ldots$ & $\ldots$ \\
\hline
\end{tabular}

PS - Production Site

AS - Assembly Site 
Table 3. Prioritizing Problem Groups

\begin{tabular}{|c|c|c|c|c|c|c|c|c|c|c|c|c|}
\hline \multirow{2}{*}{ Priorities } & \multicolumn{2}{|c|}{$\begin{array}{r}\text { Degree of } \\
\text { Difficulties }\end{array}$} & \multicolumn{6}{|c|}{ Easy } & \multicolumn{4}{|c|}{ Tough } \\
\hline & $\begin{array}{c}\text { Exigent } \\
\text { Level }\end{array}$ & & 1 & 2 & 3 & 4 & 5 & 6 & 7 & 8 & 9 & 10 \\
\hline PG8 & Must & 1 & & & PG8 & & & & & & & \\
\hline PG7 & & 2 & & & & & & & PG4 & & & \\
\hline PG5 & & 3 & & & & PG7 & & & & & & \\
\hline PG6 & & 4 & & & & & PG6 & & & & & \\
\hline PG4 & & 5 & $\mathrm{PG} 5$ & & & & & & & & & \\
\hline PG1 & Want & 1 & & & & & & PG12 & & & & \\
\hline PG3 & & 2 & & & PG1 & & & & & & & \\
\hline PG9 & & 3 & & $\mathrm{PG} 3$ & & & & & & $\mathrm{PG} 2$ & & \\
\hline PG12 & & 4 & & & PG9 & & & & & & & \\
\hline PG11 & & 5 & & & PG11 & & & & & & & \\
\hline PG13 & Tentative & 1 & PG13 & & & & & & & & & \\
\hline PG2 & & 2 & PG15 & & & & & & & & & \\
\hline PG15 & & 3 & PG14 & & & & & & & & & \\
\hline PG14 & & 4 & & & & & & & & & & \\
\hline$\ldots$ & & 5 & & & & & & & & & & \\
\hline
\end{tabular}

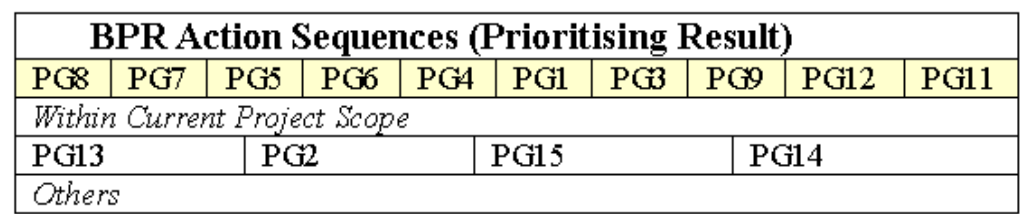

